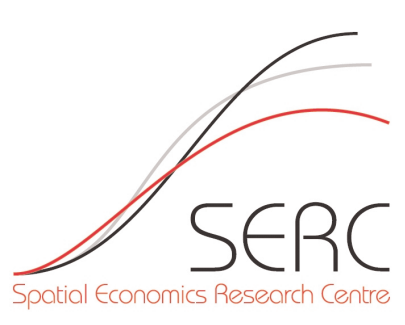

SERC DISCUSSION PAPER 77

\title{
House Prices and Credit Constraints: Making Sense of the U.S. Experience
}

John V. Duca (Federal Reserve Bank of Dallas, Southern Methodist University, Dallas)

John Muellbauer (SERC, Nuffield College, Oxford University)

Anthony Murphy (SERC, Federal Reserve Bank of Dallas)

March 2011 
This work is part of the research programme of the independent UK Spatial Economics Research Centre funded by the Economic and Social Research Council (ESRC), Department for Business, Innovation and Skills (BIS), the Department for Communities and Local Government (CLG), and the Welsh Assembly Government. The support of the funders is acknowledged. The views expressed are those of the authors and do not represent the views of the funders.

(C) J. V. Duca, J. Muellbauer and A. Murphy, submitted 2011 


\title{
House Prices and Credit Constraints: Making Sense of the U.S. Experience
}

\author{
John V. Duca* \\ John Muellbauer** \\ Anthony Murphy***
}

March 2011

* Federal Reserve Bank of Dallas, Southern Methodist University, Dallas

** SERC, Nuffield College, Oxford University

*** SERC, Federal Reserve Bank of Dallas

Acknowledgements

We thank Kurt Johnson, David Luttrell and Jessica Renier for research support, an anonymous referee and seminar participants at the 2010 Royal Economic Society Annual Conference, 2010 American Economic Association Meetings, Bank of Spain, Swiss National Bank, 2009 Spanish Applied Economics Conference, International Monetary Fund, 2009 Euro Area Business Cycle Network Conference, 2009 SUERF/Bank of Finland Housing Markets Conference, 2009 Swiss Society for Financial Market Research Meetings, the 2009 Western Economic Association International Annual Conference as well as Lancaster, Oxford and Marseilles Universities for helpful comments and suggestions. John Muellbauer gratefully acknowledges research support from ESRC via the UK Spatial Economics Research Centre and from grants by the Open Society Institute and the Oxford Martin School. The views expressed are those of the authors and do not necessarily reflect those of the Federal Reserve Bank of Dallas or the Board of Governors of the Federal Reserve System. Any remaining errors are our own. 


\begin{abstract}
Most US house price models break down in the mid-2000's, due to the omission of exogenous changes in mortgage credit supply (associated with the sub-prime mortgage boom) from house price-to-rent ratio and inverted housing demand models. Previous models lack data on credit constraints facing first-time home-buyers. Incorporating a measure of credit conditions - the cyclically adjusted loan-to-value ratio for first time buyers - into house price to rent ratio models yields stable long-run relationships, more precisely estimated effects, reasonable speeds of adjustment and improved model fits.
\end{abstract}

Keywords: house prices, credit standards, subprime mortgages

JEL Classifications: R31, G21, E51, C51, C52 


\section{House Prices and Credit Constraints: Making Sense of the U.S. Experience}

\section{John V. Duca, John Muellbauer and Anthony Murphy}

The recent boom and bust in U.S. housing markets has sparked interest in modeling the links between house prices and credit standards.

As Meen (2001), Muellbauer and Murphy (1997) and Cameron, Muellbauer and Murphy (2006) stress, inverting the effective demand for housing services implies that house prices are a function of credit constraints as well as income, the housing stock and the real user cost of housing. Kim (2007) shows theoretically that down-payment or loan-tovalue (LTV) constraints also help determine the house price-to-rent ratio. Models of U.S. house prices have been hindered by a lack of consistent time series measures of the exogenous changes in the credit constraints facing marginal, first-time home-buyers. This shortcoming suggests that most U.S. house price models suffer from omitted variable bias.

This issue is addressed using Duca, Johnson and Muellbauer (2009) data average LTV ratios from 1979 to 2007 for first-time home-buyers, the marginal group most likely 
affected by down-payment constraints. Derived from the American Housing Survey (AHS), this series implies that down-payment constraints were eased early this decade (Figure 1), in line with Doms and Krainer's (2007) finding that homeownership rates rose among the young. As discussed in Duca, Muellbauer and Murphy (2010a), the rise in LTV ratios from 2000 to 2005 likely reflects two financial innovations: the adoption of credit scoring technology that enabled the sorting and pricing of nonprime mortgages as well as the funding of such loans using collateralized debt obligations (CDOs) and credit default swap (CDS) protection. The later failure of CDOs to protect investors from unanticipated default losses and the soaring cost of using CDSs induced a reversal of the earlier easing of credit standards. Reports imply that mortgage standards have tightened further, which will likely be confirmed when we update the first time buyer LTV series following the release of the 2009 AHS data.

Before we use the first-time buyer LTV data in our econometric models of the house price-to-rent ratio, we remove the estimated effects of cyclical and other variables such as the unemployment rate. The inclusion of this adjusted first-time buyer LTV variable notably improves the models by yielding stable long-run relationships, sensible and more precisely estimated user cost coefficients, reasonable speeds of adjustment and better model fits. This is true both for the full sample (1981 to 2007) and the pre-subprime boom sample (1981 to 2001), and reflects an earlier, modest rise in LTV ratios which enables us to identify the effect of changes in mortgage credit standards in the shorter, pre-subprime boom, sample. These results, as well as the post-2001 forecasts, should reassure readers that the LTV ratio is more than just a dummy variable for the subprime boom. 
This paper is organized as follows. Section 1 presents the models and the data. These, in turn, are estimated using Engle-Granger (1987) like two-step cointegrating regressions in Section 2, except that the long-run cointegrating regressions are estimated using the Johansen $(1991,1995)$ method in the first step. More general, autoregressive distributed lag (ARDL) model estimates are also presented, as well as some alternative specifications and robustness checks based on the latest available data. The conclusion discusses the links between credit and asset market bubbles.

\section{House Price Models and Data}

\subsection{The House Price-to-Rent Ratio Approach}

House prices have been modeled using the price-to-rent approach, especially in the U.S., where good quality regional housing stock data are not readily available and rents are market-determined, in contrast to the UK. ${ }^{2}$ This approach assumes that, absent substantial frictions and credit restrictions or risk premia, arbitrage between owner-occupied and rental housing implies the house rent-to-price ratio depends on the real user cost of capital, RUSER, defined as the after-tax, nominal user cost of mortgage finance plus physical depreciation and property taxes, minus expected appreciation:

$$
R E N T / H P=R U S E R \equiv r+\delta+t-\Delta h p^{e} / h p,
$$

where $r$ is the real after-tax interest rate, $\delta$ is the depreciation rate, $t$ is the property tax rate, and $\Delta h p^{e} / h p$ is the expected real rate of house price appreciation or depreciation. RUSER is referred to as the real user cost in the paper. ${ }^{3}$

As shown by Kim (2007, p.8), this result also holds in an equilibrium model, when agency costs make renting more expensive than buying or owning a house. Inverting (1) and taking logs implies that:

\footnotetext{
${ }^{2}$ Other approaches to modeling house prices include the inverted housing demand and reduced form models, as well as ad hoc models which are difficult to theoretically interpret (Cameron, Muellbauer and Murphy, 2006). ${ }^{3}$ Note that this terminology differs from that of Jorgenson for whom the real user cost would equal our user cost term RUSER multiplied by real house prices $R H P$.
} 


$$
\ln H P R E N T=-\ln R U S E R,
$$

where HPRENT $=H P / R E N T$, the RUSER elasticity equals minus one and the price-to-rent ratio is invariant to the housing stock and deviations of income from trend. However, Kim (2007) shows that, when marginal first time buyers face binding maximum LTV constraints , the RUSER elasticity is smaller than one in size (in line with Gallin's 2006 results) and equilibrium ratios are complicated functions of the maximum LTV ratio and income fluctuations:

$$
\ln H P R E N T=f(\ln R U S E R, \max L T V, Y \text { deviation }) .
$$

Ex-post user costs can be negative if appreciation rates exceed nominal user costs. An important issue is how to track expectations of house prices. Many studies find that lagged rates of appreciation are a good proxy, suggesting an extrapolative element in household expectations. Our real user cost measure, RUSER, uses the annual rate of appreciation in house prices over the prior 4 years. Given our assumptions on transactions costs, RUSER is always positive so $\ln R U S E R$ is defined over the sample. The log transformation implies that at low values, variations in RUSER have a more powerful effect than at high values, reflecting the idea that when appreciation is high relative to nominal user costs, the market gets into a 'frenzied' state. ${ }^{4}$

\subsection{Data}

The variables fall into the following categories: home prices and rents; real user costs including capital gains, taxes and depreciation; mortgage credit standards and monetary/regulatory variables. I(1) shifts in demographic variables were not statistically or economically significant, perhaps reflecting breaks in the population data from decennial censuses. We plan further tests for demographic effects in future research.

\footnotetext{
${ }^{4}$ Hendry (1984) and Muellbauer and Murphy (1997) capture similar effects using a cubic in appreciation. In results not shown, we found that including such a cubic term yielded similar long run solutions and adjustment speeds.
} 
House prices and rents. We use Freddie Mac data on nominal home prices from repeat sales of homes and omit prices from mortgage refinancings, which are distorted by appraisers' incentives to inflate prices. To construct the house price-to-rent ratio (HPRENT), we seasonally adjust the house price data and divide them by the personal consumption expenditures price index for renting fixed dwellings, which closely parallels the ownerequivalent rent series from 1983-present.

Real user cost of housing. The user cost (RUSER) is the after-tax sum of the effective conventional mortgage interest rate and the property tax rate from the Federal Reserve Board (FRB) model, plus the FRB depreciation rate for housing minus the annualized home price appreciation over the four prior years adjusted for an assumed 8 percent cost of selling a home. The resulting real rate is positive in the sample (Figure 2), allowing real user costs to enter in logs, an appealing aspect stressed by Meen (2001). ${ }^{5}$ Real user costs in the late 1970s were roughly similar to those in 2003, and were not much above those of the mid-2000s, and yet the house price-to-rent ratio was higher in the latter period, a disparity this study attributes to changes in mortgage credit standard for first-time home-buyers.

Exogenous changes in mortgage credit standards. Mortgage credit standards are tracked by the average LTV for homes bought by first-time home buyers (Duca, Johnson, and Muellbauer, 2009) using American Housing Survey data since 1979. This series consistently tracks LTV ratios on conventional mortgages. This corresponds to the Freddie Mac house price series, which is based on homes bought with conforming, conventional mortgages. The

\footnotetext{
${ }^{5}$ The qualitative results were unchanged in some other regressions (not shown to conserve space) when the level of the real user cost was used instead of the log real user cost. Nevertheless, the log models had smaller standard errors and faster speeds of adjustment than the semi-log models, consistent with findings reported in Meen (2001).
} 
LTV series shifted up slightly, from a range around $85 \%$ in the late 1970 s and the 1980 s, to a range near 87 percent in the 1990s (Figure 1), before jumping after 2002.

We adjust the raw quarterly LTV data for two reasons. First, we adjust the data for shifts in the average age of the borrower, seasonality, regional composition and some unusually small quarterly samples. We wish to filter out these demand shifts and noisy observations. Second, we examined the endogeneity of the first-time home buyer LTVs by assessing its correlation with several cyclical variables over 1979-2007. We found no significant link with income and interest rates, but LTV's are correlated with changes in the unemployment rate $(U)$. To estimate these effects, Duca, Johnson, and Muellbauer (2009) regress the raw, simple mean average LTV ratio on the above variables, in the presence of the Hodrik-Prescott filtered LTV $\left(L T V^{H P}\right)$ to control for LTV trends, as well as dummies for two unusual episodes which would otherwise distort estimates. The latter were the quarter following the September 11, 2001 terrorist attacks (SEPT11), which induced a temporary plunge in the LTV ratio, and the two quarters after the passage of thrift bailout law in 1989 q3, which temporarily disrupted lending because savings and loan institutions were seized before being later closed (FIRREA). The resulting regression is:

$$
\begin{aligned}
L T V_{t}(\text { raw }) & =\underset{(1.37)}{0.0826}-\underset{(-3.02)}{0.0179} \Delta U_{t}-\underset{(-2.44)}{0.0023} A G E_{t}+\underset{(-2.44)}{0.0749} W E S T_{t}-\underset{(-6.20)}{0.0620 S E P T 11_{t}} \\
& +\underset{(-3.70)}{0.9773} L T V_{t}^{H P}-\underset{(-3.70)}{0.0473} \text { FIRREA }_{t}+\underset{(1.42)}{0.0825} L T V_{t-1}
\end{aligned}
$$

where t-statistics are shown in parentheses, $\mathrm{R}^{2}=0.850$, standard error $=0.0168, \mathrm{LM}$ statistics for $\mathrm{AR}(2) / \mathrm{MA}(2)$ errors $=1.64$, and the regression included quarterly seasonal dummies and dummy variables for quarters with less than 20 observations. WEST, the western share of first-time buyers per quarter, is the only Census regional share variable that was close to being statistically significant. The positive coefficient on WEST plausibly reflects the impact of higher home prices in that region on preferences with respect to LTV ratios and the tendency for faster home price appreciation in that region, which may make lenders feel comfortable with smaller down-payment cushions. The negative coefficient on age reflects 
the fact that older households tend to be wealthier and would either be able to or would prefer to borrow at a lower LTV.

The adjusted series equals the raw series minus all of the above effects except that of the lagged dependent variable, FIRREA and the H-P filtered LTV. In order to obtain similar means for the raw and adjusted LTV series, $(1-0.9773) * L T V^{H P}$ was also subtracted from the raw series. To smooth the series, we then took a three-quarter, weighted average moving average of the resulting series using quarters $t$ through $t-2$, where the weights are the relative share of observations in each of the three quarters.

The post 2001 rise in LTV ratios likely reflects two financial innovations that fostered the securitized financing of riskier mortgages, as noted above. The use of credit scoring technology enabled lenders to sort nonprime borrowers and price the risk of nonprime mortgages. Since these loans were too risky for banks to hold, they were funded by securities markets, where investor demand for the mortgage-backed securities funding nonprime loans was temporarily boosted by two other developments. First, the combination of very low interest rates and expanded credit availability in the early 2000s fueled a rise in house prices that plausibly led investors and analysts to under-estimate the default risk on nonprime mortgages. ${ }^{6}$ Second, regulatory and policy changes boosted the demand for the securities funding nonprime mortgages. These included a 2004 SEC decision to double the 1935 limits on investment bank leverage and the rise of hedge funds and SIVs that used short-duration debt to fund holdings of nonprime mortgages. Also important were large purchases of nonprime MBS by Fannie Mae and Freddie Mac to meet public policy goals of raising home ownership (Frame, 2008), even though they did not issue much nonprime MBS. Nonprime mortgage securities sold to these government sponsored enterprises (GSEs) and private

\footnotetext{
${ }^{6}$ As DiMartino and Duca (2007) argue, the short history of subprime mortgages may have tempted analysts to forecast the incidence of problem loans using labor market conditions, while not having enough data to disentangle the effects of house prices and interest rates. In addition, the tendency for vintages of Alt A mortgages to have progressively higher proportions of no- or low-documentation of income (Credit Suisse 2007) and to post progressively worse loan quality (Mayer, Pence, and Sherlund, 2009) suggests that an errors-
} 
investors were often collateralized debt obligations (CDOs) or protected by credit default swaps (CDSs). The subsequent failure of CDOs to shield investors from unexpected losses and later jump in CDS costs led to a collapse in the funding and availability of nonprime mortgages.

Capital gains tax changes. The real user cost variable does not account for changes in capital gains taxation. Before mid-1997, net capital gains on home sales were taxable for households under age 55 if the seller did not purchase a home of equal or greater value. The Tax Reform Act of 1997, passed in 1997 q2, largely eliminated this tax by exempting the first $\$ 500,000(\$ 250,000)$ of gains for married (single) filers, raising the after-tax value of homes and turnover (Cunningham and Englehardt, 2008). To control for this, we included, CAPGAINTAX, equal to 1 since $1997 \mathrm{q} 3$ and 0 before. $^{7}$ The third quarter timing reflects the 1-2 month lag between the signing and actual settlement (when house prices are recorded) of home sale contracts. We use the t-2 lag of CAPGAINTAX, which was the most significant lag and yielded white noise-like model residuals.

Monetary and regulatory variables. We include several monetary policy and regulatory controls in house price-to-rent models to improve model estimates. Our MONEYTARGET indicator variable equals 1 (and 0 elsewhere) over the money targeting regime of 1979 q4 to 1982 q3, which may have reduced mortgage supply and demand by raising interest rate uncertainty. Another variable is the t-1 lag of $R E G Q$, Duca's (1996) measure of how much Regulation Q ceilings on deposit interest rates were binding until these controls were lifted in the early 1980s. REGQ controls for negative short-run disintermediation effects not tracked by the user cost of capital (Duca and Wu, 2009).

in-variables problem, from overstatements of borrower income, contributed to the underestimation of nonprime mortgage defaults.

\footnotetext{
${ }^{7}$ In other runs, we found that the effects of another tax variable were not robust. This variable was the time over which rental properties can be depreciated, which may raise the after-tax cost of renting relative to home prices.
} 
Another variable controls for a large rise in the upfront insurance premium for Federal Housing Administration (FHA) loans in 1983. The FHA provides government guarantees against losses to lenders. Until 2007, FHA loans had loan size limits well below those on "conventional" mortgages. The FHA announced a rise in its upfront premium from $0 \%$ to $3.8 \%$ of mortgage principal was to take effect in late $1983 \mathrm{q} 3$, inducing many renters to speed up leaving rental housing and purchase "starter" homes in that quarter. This induced intertemporal substitution shifted the timing of home sales forward from two quarters later. To capture this substitution effect we include a dummy $\left(\triangle F H A F E E_{t}\right)$ equal to 1 in $1983 \mathrm{q} 3,-1$ in $1984 \mathrm{q} 1$ and 0 otherwise to control for the associated large jump in house prices in 1983 q3 that unwound in $1984 \mathrm{q} 1$.

\section{Long-Run and Short-Run Results from Cointegration Models}

The long run variables in our house price to rent ratio models have a unit root, so we present our cointegrating regression results first. We then set out some more general autoregressive, distributed lag (ARDL) findings. In both sets of results, we control for tax effects by using income and property tax rates to calculate real user costs, and control for the money targeting regime of 1979-1982 that imparted more interest rate risk to house prices beyond that reflected in user costs. By addressing these important influences, we try to avoid omitted variable bias that can obscure long-run relationships and lead to poorly estimated coefficients.

In the house price-to rent approach, we assess the importance of mortgage availability using our cyclically adjusted LTV ratio for first-time buyers, which we believe captures exogenous shifts in mortgage availability which are unrelated to incomes and interest rates. These shifts alter the relative demand for owner-occupied versus rental housing, by raising the effective demand for owner-occupied housing of the credit constrained and lowering their effective demand for rental housing. The first example is a small shift up in the LTV ratios in 
the early 1990s that coincided with new guidelines imposed by Congress on Fannie Mae and Freddie Mac to fund low down-payment mortgages to raise home-ownership rates (Gabriel and Rosenthal, 2010). The second major example of such an LTV increase is the rise of our LTV series in the early 2000's associated with financial innovations that coincided with a jump in non-prime (subprime and other non-conforming) mortgage lending and the overall homeownership rate. The resulting demand shifts can alter the equilibrium price-to-rent ratio by affecting the land intensity of housing, since the supply of land is not as price elastic as is the supply of structures (Davis and Heathcote, 2005).

House price-to-rent models usually estimate a long-run relationship between user costs and the price-to-rent ratio, and often imply that U.S. home prices were over-valued in 2005. Exceptions to the latter are city or regional models that either (i) use a very low real user cost of housing, assuming that unusually high rates of local house price appreciation in the mid 2000's would persist (e.g. Himmelberg, Mayer, and Sinai, 2006), or (ii) argue that rents are higher in high cost areas than implied by official data (Smith and Smith, 2006). We use standard measures of rents and national house price appreciation rates to construct real user cost of capital measures. We depart from the literature by including our cyclically adjusted measure of LTV ratios for first-time home buyers in cointegrating vectors containing the home price-to-rent ratio and user cost of capital. We also compare our long-run and shortrun results to the results obtained using models that omit the LTV ratio.

\subsection{Long-Run Results}

The upper panel of Table 1 reports the estimated long run price-to-rent models. The estimates were generated using data from 1979 to 2007 and the Johansen $(1991,1995)$ procedure, allowing for deterministic trends in the long-run variables but not in the cointegrating vector. The short run results set out in the lower panel are from a second step VAR in first differences which includes the equilibrium-correction term estimated in the first step. Lag lengths were long enough to yield statistically significant unique cointegrating 
vectors, minimize the AIC statistics and yield approximately white noise residuals. Models 1 to 3 exclude our adjusted LTV measure of credit constraints, whilst models 5 to 6 include the LTV variable. Models 2 and 5 are used to check the stability of the non-LTV and LTV models. They are estimated using data ending in $2001 \mathrm{q} 4$, prior to the subprime boom starting in 2002. The other models were estimated up to 2007 q2. Models 3 and 6 include the Regulation Q and FHA premium short-run variables to control for unusual regulatory influences that affected the mortgage availability.

As implied by the trace and maximal eigenvalue statistics, highly significant, unique cointegrating vectors were found for all three LTV models. In the non-LTV models, there was weaker or no evidence of a unique cointegrating vector. Although a unique cointegrating vector for the non-LTV model could be found in the full sample (model 1), a unique, significant vector was not found in the pre-2002 sample. Ceteris paribus, the test statistics show stronger evidence of cointegration for models including the adjusted LTV ratio (models 4 to 6) than for models without the ratio (models 1 to 3 ).

As expected, the long-run coefficient estimates imply that the price-to-rent ratio is negatively and significantly related to the real user cost of housing, and positively and significantly related to the LTV ratio. The estimated long-run user cost coefficients are also statistically different from -1, rejecting a major implication of perfect capital markets (Kim, 2007) with coefficient estimates near those of Gallin (2008). ${ }^{8}$ Furthermore, in the vector equilibrium correction models, the equilibrium-correction term was significant in the priceto-rent equations (full sample t-statistics of -5.8) but was insignificant in the equivalent LTV model (t-statistic of -1.39). These tests of weak exogeneity suggest that the cyclically

\footnotetext{
${ }^{8}$ Other reasons for the low user cost coefficient include ill-informed home-buyers and lumpy transactions costs.
} 
adjusted LTV ratios for first-time home-buyers are statistically exogenous to house prices, but that house prices are not exogenous to these LTV ratios.

The estimated equilibrium price-to-rent ratios from the LTV models also track the data better than estimates from the non-LTV models. Figure 3 plots the two-quarter lags of the estimated equilibrium house price-to-rent ratios from LTV and non-LTV models (models 5 and 2 respectively) estimated using our short (pre-subprime boom) sample. The equilibrium price-to-rent ratios from the LTV model line up better with the actual data than the non-LTV model ratios. In particular, the LTV model is better at tracking the peak and ebb of the house price-to-rent ratio in 2006-07, consistent with the view that easier mortgage credit standards fueled the home price boom of the mid-2000s. This finding is reassuring - the LTV ratio is not just a dummy for the subprime boom and bust. The early-1990s upward shift in the adjusted first time buyer LTV ratio corresponds to a change in downpayment policies at the GSE's (e.g. Fannie Mae and Freddie Mac) and the upward shifts in the ratio in the early to mid 2000s reflect well documented financial innovations.

\subsection{Short-Run Results}

An easing of mortgage credit standards also has large short-run effects on home prices, as shown in the bottom part of Table 1 which reports the vector equilibrium-correction model results for the change in the house price-to-rent ratio based on the estimated long-run equilibrium relationships. In the LTV models, the equilibrium-correction term is highly significant with adjustment speeds of between $11 \%$ and $13 \%$ per quarter. By contrast, adjustment speeds in the non-LTV models are much slower, ranging between $2 \%$ and $6 \%$ per quarter. They are also less significant, reflecting the inferior ability of non-LTV models to track long-run relationships. This is especially true for full sample models that include the 
full set of control variables (models 3 and 6), where the speed of adjustment is $13 \%$ in the LTV model versus $3 \%$ in the non-LTV model. Comparing similar LTV and non-LTV models indicates that including the LTV ratio terms improves the adjusted $R^{2}$ by 3 to 4 percentage points and lowers standard errors by more than one tenth. There are some significant short run dynamics. For example, last quarter's change in the log house price-torent ratio has a significantly positive effect on the current log price-to-rent ratio, even though lagged house price appreciation over a longer period is incorporated in log RUSER.

\subsection{Some ARDL Results}

As a robustness check, Table 2 sets out some autoregressive distributed lag model estimates. The results are very similar to the vector equilibrium correction model results in Table 1. Relative to corresponding non-LTV models, the LTV models in Table 2 fit better and have faster speeds of adjustment, especially over the full sample. ${ }^{9}$

\subsection{Alternative Specifications}

We examine two additional issues as a further check on the robustness of our findings. The first concerns a shortcoming of the repeat sales index - it overstates house price rises by ignoring home improvements. To address this, we construct and analyze a house price index adjusted for home improvements. We first cumulated a quarterly Census series on home structure improvements (which ends in 2007), and adjusted the resulting series for depreciation. The depreciation-adjusted stock of home improvements is then scaled by the FRB Flow of Funds estimates of the replacement cost value of residential home structures. This yields a time series of the relative importance of home improvements as a source of housing stock accumulation. We multiply this series by the Freddie Mac repeat home sales

\footnotetext{
${ }^{9}$ Lagged first differences of the LTV and real user cost terms were insignificant and are not included in the models presented.
} 
price index to adjust repeat home sales prices for home improvements. This adjusted price index is used to construct an adjusted price-to-rent ratio (HPRENTADJ) and an adjusted real user cost of capital. Some results are reported in models 1 and 2 in Table 3, which correspond to models 3 and 6 in Table 2. These models cover the full sample, use all of the controls, and yield similar results. Again, models using our adjusted first time buyer LTV variable to control for changes in mortgage credit conditions yield better fits with faster speeds of adjustment.

The second robustness issue has to do with simulating the price-to-rent ratio through 2009 q4, which is outside of our LTV data sample. This entails simulating a path for the LTV ratio, adjusting the user cost for the housing tax credit of 2009, taking account of changes in government lending programs and including a dummy variable to gauge the extra impact of the financial crisis. Regarding the LTV path, Sherlund (2008) shows that subprime lending essentially disappeared between 2007 q2 and 2007 q4 and that LTVs for securitized mortgages fell back to late 1999 levels by the end of 2007. Using this as a benchmark, our assumed LTV path plunges evenly between 2007 q2 and 2007 q4 to its 1999 q4 level, where it remains.

We also model the impact of the 2009 income tax credit of $10 \%$ of a home's purchase price up to a cap of $\$ 8,000$ for couples who were first-time home buyers (non-owneroccupiers in the prior three years). The credit covers homes bought between the $1^{\text {st }}$ January and $30^{\text {th }}$ November 2009, but the deARDLine was later extended to the $30^{\text {th }}$ June $2010 .{ }^{10} \mathrm{We}$ calibrate the tax credit by dividing the $\$ 8,000$ cap by the average price of existing singlefamily homes sold between $2007 \mathrm{q} 4$ and 2008 q3. We adjust the resulting $3.28 \%$ figure for

\footnotetext{
${ }^{10}$ The 2008 "tax credit" loan, which the borrower had to pay back to the Treasury, had little effect on house prices.
} 
the fact that first-time buyers, on average, bought a home that was $20 \%$ less expensive than the average price of all homes purchased reported in the 2005 AHS. Applying the 20\% adjustment to the sales price, results in a $4.11 \%$ tax credit figure. This basically treats the tax credit as having an effect proportional to its impact on real user costs facing the marginal (i.e. first-time) home buyer. The law containing the credit was passed late in 2009 q1, but the housing tax credit was non-controversial. The trajectory of most house price series changed dramatically in 2009 q1. For simplicity, we adjusted the real user cost RUSER by subtracting 4.11 percentage points for the quarters $2008 \mathrm{q} 4$ through $2010 \mathrm{q} 1$. We advance the dating by one quarter because RUSER enters the model with at least a one period lag. This defines the variable denoted by $R U C A D J$.

We also examined changes in the Federal Housing Administration (FHA) mortgage program. Before the subprime bust, the limits on the size for loans eligible for FHA financing were well below those conforming mortgages securitized by Freddie Mac and Fannie Mae. FHA loans also carried a large, upfront premium equal to $1.5 \%$ of the loan amount, plus a continuing, non tax-deductible premium of $0.5 \%$ added to the mortgage rate for the first 5 to 10 years of the mortgage, depending on the LTV ratio at the time of purchase. These features made conventional financing preferable for most first-time buyers, who did not need the 96.5 percent LTV cap on FHA loans. Before 2008 q1, FHA loans had a maximum loan ceiling $(\$ 200,160)$ that was lower than the ceiling for conventional mortgages $(\$ 417,000)$. Since then, the FHA limit for many areas was raised to $\$ 271,050$, versus $\$ 417,000$ for conforming loans. In addition, new mortgage size limits of $\$ 729,000$ for both FHA and Freddie/Fannie loans were created for high cost areas starting in 2008 q1. With the collapse of subprime lending, the share of mortgage originations insured by the FHA rose, while the conventional share fell. ${ }^{11}$ We account for these changes by including the gap (FHALTVGAP) between the FHA LTV limit of 96.5 percent and the simulated LTV starting

\footnotetext{
${ }^{11}$ See http://www.huduser.org/periodicals/ushmc/winter08/nat_data.pdf .
} 
in 2008 q1. Since the latter is flat, this is tantamount to adding a dummy equal to 1 since 2008 q1.

Finally, we also tried to control for the plunge in housing demand during the recent financial crisis. In addition to including a dummy (FINCRISIS) equal to 1 in $2008 \mathrm{q} 4$ (Lehman failed just before 2008 q4), we also tried a continuous variable to control for consumer credit availability. This variable, DCREXOG, is the first difference of an index of the share of banks reporting an increasing willingness to make consumer installment loans from a quarter earlier. Following Duca, Muellbauer and Murphy (2010b), this index is adjusted for changes in interest rates, consumer loan delinquency rates and the economic outlook (using the index of leading economic indicators). Although the variable is contemporaneous, adjusting for interest rate and cyclical factors reduces the scope for simultaneity bias. Positive readings of CREXOG are likely to boost effective housing demand, by making it easier for marginal, first-time home-buyers to indirectly fund mortgage down-payments by using consumer credit to buy non-housing goods and services. Moreover, the estimated coefficient on this variable was similar for samples ending in 2007 q2 and 2009 q3, implying that its impact around the recent financial crisis was in line with past experience. Including DCREXOG in our regressions may help disentangle the effects of general uncertainty during the financial crisis, as captured by the dummy variable FINCRISIS, from the increased difficulty first-time buyers faced in meeting LTV constraints.

We estimated an additional four ARDL models over the 1980 q4 to 2009 q4 sample period, similar to the models in Table 2. The first model (model 3 in Table 3) uses the LTVADJ variable, with no controls for the 2009 tax credit, changes in FHA lending limits or consumer credit availability. The second (model 4) differs by replacing RUSER with RUCADJ to control for the tax credit. The third model (model 5) adds DCREXOG and FHALTVGAP to control for changes in consumer credit availability and FHA lending limits. The fourth model (model 6) omits the insignificant FHALTVGAP from model 5. 
Several patterns emerge from the results in Table 3 and simulation paths in Figure 4. First, comparing models 3 and 4 shows that adjusting the real user cost for the tax credit improves model fit. ${ }^{12}$ Second, in model 5, the FHA LTV gap variable is insignificant. Third, the presence of the DCREXOG variable indicates that there can be contemporaneous spillover effects from changes in consumer credit availability on real house prices and these effects are significant, without affecting the estimated LTV effects on house prices. Fourth, including DCREXOG barely affects the coefficient on the financial crisis dummy, which did not have a significant additional effect on housing demand beyond information in other variables. As shown in Figure 5, there is some improvement in fit in 2009 from shifting from model 3 to model 4, which shows the estimated impact of the tax credit via the real user cost term. Also accounting for consumer credit availability only helps slightly. These results indicate that the tax credit notably bolstered recent house prices, with consumer credit availability slightly restraining house prices.

\section{Conclusion}

Our findings provide a theoretically appealing and empirically consistent account of the behavior of U.S. house prices. In a price-to-rent framework, credit standards for firsttime home-buyers significantly affect house prices, in line with theory (e.g. Ortalo-Magne and Rady, 2006) and results challenging standard price-rent models (e.g. Gallin, 2008). Similar results are obtained using the Loan Performance house price index and using house price models based on an approach which inverts the demand for housing services (appendix available upon request). These findings support the view that a sizable easing of U.S. mortgage standards, as reflected in the cyclically adjusted LTV ratios for first-time home-

\footnotetext{
${ }^{12}$ In another regression not shown, we added a dummy for the tax credit to model 3, which was significant but improved the model fit by less than replacing RUCADJ with RUSER.
} 
buyers, raised the effective demand for housing in the early 2000s (Duca, Muellbauer and Murphy, 2010a). Between early 2005 and mid-2007, there was a partial reversal of that easing, and almost certainly further reversals since the mortgage-related financial market turmoil which started in August 2007 and intensified during the Fall of 2008.

Most empirical models of US home prices lack a measure of mortgage credit standards and thus suffer from a serious omitted variable bias, rendering them less capable of tracking the earlier surge of home prices during the mortgage boom and the unwinding of much of that appreciation during the early phases of the subprime bust. In contrast, models including a cyclically adjusted LTV measure for first time home-buyers yield sensible and statistically significant long-run relationships, more precise estimates of key coefficients, reasonable speeds of adjustment and better model fits. Furthermore, our credit-augmented models imply that much of the boom-bust cycle in U.S. home prices stemmed from an easing and subsequent tightening in U.S. mortgage standards affecting potential marginal homebuyers. Our models suggest that loan-to-value ratios for private sector mortgages for first time buyers have returned to levels near those of 2000, although the tax credit for first-time home-buyers may have cushioned much of the impact of tighter mortgage standards. From a broader perspective, our results are consistent with the view that many asset bubbles are linked to an unsustainable easing of credit standards or adoption of risky financial practices that eventually unwind during a subsequent bust.

Federal Reserve Bank of Dallas and Southern Methodist University, Dallas.

Nuffield College, Oxford.

Federal Reserve Bank of Dallas. 


\section{References}

Cameron, G., Muellbauer, J. and Murphy, A. (2006), "Was There a British House Price Bubble? Evidence from a Regional Panel”, Centre for Economic Policy Research discussion paper no. 5619.

Capozza, D. and Seguin, P. (1996), "Expectations, Efficiency, and Euphoria in the Housing Market”, Regional Science and Urban Economics, 26, 369-86.

Case, K. E. and Shiller, R. J. (1988), “The Behavior of Home Buyers in Boom and PostBoom Markets", New England Economic Review, Federal Reserve Bank of Boston, November/December, 29-46.

Case, K. E. and Shiller, R. J. (1989), “The Efficiency of the Market for Single-Family Homes", American Economic Review, 79, 125-37.

Case, K. E. and Shiller, R. J. (1990), "Forecasting Prices and Excess Returns in the Housing Market", Journal of the American Real Estate and Urban Economics Association, 18, 253-73.

Clayton, J. (1996), "Rational Expectations, Market Fundamentals and Housing Price Volatility", Real Estate Economics, 24, 441-70.

Clayton, J. (1997), “Are Housing Price Cycles Driven by Irrational Expectations?”, Journal of Real Estate Finance and Economics, 14, 341-63.

Credit Suisse (2007), “Mortgage Quality Du Jour: Underestimated No More,” March 13.

Cunningham, C. R. and Englehardt, G. V. (2008), "Housing Capital-Gains Taxation and Homeowner Mobility: Evidence from the Taxpayer Relief Act of 1997”, Journal of Urban Economics, 63(3), 803-15.

Davis, M. A. and Heathcote, J. (2005), "The Price and Quantity of Residential Land in the United States", International Economic Review, 46, 751-84.

DiMartino, D. and Duca, J. V. (2007), “The Rise and Fall of Subprime Mortgages”, Federal Reserve Bank of Dallas Economic Letter, November, 1-8. 
Doms, M. and Krainer, J. (2007), "Innovations in Mortgage Markets and Increased Spending on Housing”, Federal Reserve Bank of San Francisco working paper number 05.

Duca, J. V. (1996), "Deposit Deregulation and the Sensitivity of Housing", Journal of Housing Economics, 5, 207-26.

Duca, J. V. (2006), "Making Sense of the U.S. Housing Slowdown”, Federal Reserve Bank of Dallas Economic Letter, November, 1-8.

Duca, J. V., Johnson, K. B. and Muellbauer, J. (2009), "Time Series Estimates of U.S. Mortgage Constraints and Regional Home Supply”, mimeo, Federal Reserve Bank of Dallas.

Duca, J. V., Muellbauer, J. and Murphy, A. (2010a), "Housing Markets and the Financial Crisis of 2007-2008: Lessons for the Future”, Journal of Financial Stability, 6, 20317.

Duca, J. V., Muellbauer, J. and Murphy, A. (2010b), “The Impact of the Financial Crisis on Consumption: Credit Constraints and Wealth Effects", mimeo, Federal Reserve Bank of Dallas. 2010 Swiss Society for Financial Market Research Meeting presentation.

Duca, J. V. and Wu, T. (2009), "Regulation and the Neo-Wicksellian Approach to Monetary Policy”, Journal of Money, Credit, and Banking, 41(3), 799-807.

Engle, R. F. and Granger, C. W. J. (1987), "Cointegration and Error Correction: Representation, Estimation and Testing”, Econometrica, 55, 251-276.

Frame, W. S. (2008), “The 2008 Federal Intervention to Stabilize Fannie Mae and Freddie Mac", Journal of Applied Finance, 18(2), 124-36.

Gabriel, S. and Rosenthal, S. (2010), "Do the GSE's Expand the Supply of Mortgage Credit?" mimeo, 2010 AEA Annual Conference presentation.

Gallin, J. (2006), “The Long-Run Relationship between Home Prices and Income: Evidence from Local Housing Markets”, Real Estate Economics, 34(3), 417-38. 
Gallin, J. (2008), “The Long-Run Relationship between Home Prices and Rents”, Real Estate Economics, 36(4), 635-58.

Hamilton, B. and Schwab, R. (1985), "Expected Appreciation in Urban Housing Markets", Journal of Urban Economics, 18, 103-18.

Hendry, D. F. (1984), "Econometric Modelling of House Prices in the United Kingdom”, in Hendry, D. F. and Wallis, K. F. (eds.), Econometrics and Quantitative Economics, Oxford: Basil Blackwell.

Himmelberg, C., Mayer, C. and Sinai, T. (2005), “Assessing High House Prices: Bubbles, Fundamentals, and Misperceptions", Journal of Economic Perspectives, 19, 67-92.

Johansen, S. (1991), "Estimation and Hypothesis Testing of Cointegration Vectors in Gaussian Vector Autoregressive Models”, Econometrica, 59, 1551-80.

Johansen, S. (1995), Likelihood-based Inference in Cointegrated Vector Autoregressive Models, Oxford: Oxford University Press.

Kim, Y. (2007), “Accounting for Housing Price-Rent Ratios, 1975-2004”, mimeo, University of Southern California,

Mayer, C., Pence, K. and Sherlund, S. M. (2009), “The Rise in Mortgage Defaults”, Journal of Economic Perspectives, 23, Winter, 27-50.

Meen, G. (2001), Modeling Spatial Housing Markets: Theory, Analysis, and Policy,. Norwell, Massachusetts: Kluwer Academic Publishers.

Meese, R. and Wallace, N. (1994), “Testing the Present Value Relation for Housing Prices: Should I Leave My House in San Francisco?", Journal of Urban Economics, 35, 24566.

Muellbauer, J. and Murphy, A. (1997), "Booms and Busts in the U.K. Housing Market", The Economic Journal, 107, 1701-27.

Ortalo-Magne F. and Rady, S. (2006), "Housing Market Dynamics: On the Contribution of Income Shocks and Credit Constraints", Review of Economic Studies, 73, 459-485. 
Smith, M. H. and Smith, G. (2006), "Bubble, Bubble, Where's the Housing Bubble?", Brookings Papers on Economic Activity, 37(1), 1-68. 
Table 1: Equilibrium Correction Models of the Change in the U.S. Log House Price-To-Rent Ratio

(A) Maximum likelihood estimates of the long-run equilibrium relationship $\ln H P R E N T_{t}=$ $\beta_{0}+\beta_{1} \ln$ RUSER $_{t-1}+\beta_{2} \ln L T V_{t-1}+u_{t}$ using a three equation system with (at most) one cointegrating vector.

No LTV Terms

\section{Model}

Sample

$\ln R U S E R_{\mathrm{t}-1}$

$\ln L T V_{\mathrm{t}-2}$

Constant

Eigenvalues

Trace Statistics:

$\begin{array}{lccc}1 \text { Vector } & 19.177^{*} & 12.696 & 19.102^{*} \\ 2 \text { Vectors } & 3.526 & 1.7119 & 3.703 \\ \lambda \text { Max Statistics: } & & & \end{array}$

1 Vector

2 Vectors

$$
15.651 *
$$

10.985

$15.399 *$

$\begin{array}{ccc}(1) & (2) & (3) \\ 1981 \mathrm{q} 1- & 1981 \mathrm{q} 1- & 1981 \mathrm{q} 1- \\ 2007 \mathrm{q} 2 & 2001 \mathrm{q} 4 & 2007 \mathrm{q} 2 \\ & & \\ -0.2285^{* *} & -0.1441^{* *} & -0.2053^{* *} \\ (11.05) & (3.81) & (12.30)\end{array}$

3.526

1.711

3.703

With LTV Terms

\begin{tabular}{ccc}
\hline$(4)$ & $(5)$ & $(6)$ \\
$1981 \mathrm{q} 1-$ & $1981 \mathrm{q} 1-$ & $1981 \mathrm{q} 1-$ \\
$2007 \mathrm{q} 2$ & $2001 \mathrm{q} 4$ & $2007 \mathrm{q} 2$ \\
& & \\
$-0.1471^{* *}$ & $-0.1363^{* *}$ & $-0.1508^{* *}$ \\
$(16.42)$ & $(7.43)$ & $(23.58)$ \\
$1.0494^{* *}$ & $0.9198^{* *}$ & $0.9368^{* *}$ \\
$(6.14)$ & $(5.15)$ & $(7.51)$ \\
1.085 & 1.0441 & 1.0751 \\
& & \\
0.2429 & 0.3062 & 0.3572 \\
0.0909 & 0.0561 & 0.0891 \\
& & \\
$40.331 * *$ & $36.106 * *$ & $58.128 * *$ \\
10.832 & 5.396 & 11.277 \\
& & \\
$29.499 * *$ & $30.701 * *$ & $46.851 * *$ \\
10.097 & 4.850 & 9.896
\end{tabular}

(B) OLS estimates of the speed of adjustment and short-run dynamics using the estimated equilibrium correction terms in (A), EC $C_{t}=\ln H P R E N T_{t}-\widehat{\beta}_{0}-\widehat{\beta}_{1} \ln R U S E R_{t-1}-\widehat{\beta}_{2} \ln L T V_{t-1}$.

No LTV Terms

\begin{tabular}{lccc}
\cline { 2 - 4 } Model & $(1)$ & $(2)$ & $(3)$ \\
Sample & $1981 \mathrm{q} 1-$ & $1981 \mathrm{q} 1-$ & $1981 \mathrm{q} 1-$ \\
& $2007 \mathrm{q} 2$ & $2001 \mathrm{q} 4$ & $2007 \mathrm{q} 2$ \\
Constant & & & \\
& -0.0007 & -0.0002 & 0.0003 \\
EC $_{\mathrm{t}-1}$ & $(0.42)$ & $(0.48)$ & $(0.91)$ \\
& $-0.0239^{+}$ & $-0.0570^{*}$ & $-0.0327^{*}$ \\
MONEYTARGET $_{\mathrm{t}}$ & $-0.0084^{* *}$ & $-0.0091^{* *}$ & -0.0022 \\
& $(2.88)$ & $(2.89)$ & $(0.72)$ \\
CAPGAINTAX $_{\mathrm{t}-2}$ & $0.0038^{* *}$ & $0.0054^{* *}$ & $0.0038^{* *}$ \\
& $(3.42)$ & $(3.28)$ & $(3.65)$ \\
REGQ $_{\mathrm{t}-1}$ & & & $-0.0068^{* *}$ \\
& & & $(3.95)$ \\
SFHAFEE & & & $0.0064^{*}$ \\
& & & $(2.64)$ \\
$\ln$ HPRENT $_{\mathrm{t}-1}$ & $0.9809^{* *}$ & $0.8505^{* *}$ & $0.9057^{* *}$ \\
& $(8.89)$ & $(7.34)$ & $(9.11)$
\end{tabular}

LTV Terms

\begin{tabular}{ccc}
\hline$(4)$ & $(5)$ & $(6)$ \\
$1981 \mathrm{q} 1-$ & $1981 \mathrm{q} 1-$ & $1981 \mathrm{q} 1-$ \\
$2007 \mathrm{q} 2$ & $2001 \mathrm{q} 4$ & $2007 \mathrm{q} 2$ \\
& & \\
0.0002 & -0.0003 & 0.0000 \\
$(0.57)$ & $(0.66)$ & $(0.16)$ \\
$-0.1059^{* *}$ & $-0.1343^{* *}$ & $-0.1274^{* *}$ \\
$(4.71)$ & $(5.03)$ & $(5.77)$ \\
$-0.0116^{* *}$ & $-0.0130^{* *}$ & $-0.0083^{* *}$ \\
$(4.67)$ & $(4.26)$ & $(3.00)$ \\
$0.0054^{* *}$ & $0.0063^{* *}$ & $0.0062^{* *}$ \\
$(5.09)$ & $(4.75)$ & $(6.10)$ \\
& & $-0.0067 * *$ \\
& & $(4.35)$ \\
& & $0.0064^{*}$ \\
& & $(3.04)$ \\
$0.9491^{* *}$ & $0.7657^{* *}$ & $0.7745^{* *}$ \\
$(9.70)$ & $(7.02)$ & $(8.35)$
\end{tabular}


Table 1 (Continued)

No LTV Terms

With LTV Terms

\begin{tabular}{|c|c|c|c|c|c|c|}
\hline & & & & & & \\
\hline Model & (1) & (2) & (3) & (4) & $(5)$ & (6) \\
\hline Sample & $\begin{array}{l}\text { 1981q1- } \\
2007 q 2\end{array}$ & $\begin{array}{l}\text { 1981q1- } \\
2001 q 4\end{array}$ & $\begin{array}{l}\text { 1981q1- } \\
2007 q 2\end{array}$ & $\begin{array}{l}\text { 1981q1- } \\
2007 q 2\end{array}$ & $\begin{array}{l}\text { 1981q1- } \\
2001 q 4\end{array}$ & $\begin{array}{l}\text { 1981q1- } \\
2007 q 2\end{array}$ \\
\hline$\Delta \ln H P R E N T_{\mathrm{t}-2}$ & $\begin{array}{c}-0.5232 * * \\
(3.44)\end{array}$ & $\begin{array}{c}-0.3551 * \\
(2.31)\end{array}$ & $\begin{array}{c}-0.4227 * * \\
(3.13)\end{array}$ & $\begin{array}{c}-0.4412 * * \\
(-3.31)\end{array}$ & $\begin{array}{c}-0.2174 \\
(-1.52)\end{array}$ & $\begin{array}{c}-0.2118^{+} \\
(-1.67)\end{array}$ \\
\hline$\Delta \ln R U S E R_{\mathrm{t}-1}$ & $\begin{array}{c}-0.0042 \\
(0.61)\end{array}$ & $\begin{array}{c}-0.0083 \\
(0.73)\end{array}$ & $\begin{array}{c}0.0019 \\
(0.30)\end{array}$ & $\begin{array}{c}0.0006 \\
(0.10)\end{array}$ & $\begin{array}{c}-0.0020 \\
(0.18)\end{array}$ & $\begin{array}{c}0.0091 \\
(1.53)\end{array}$ \\
\hline$\Delta \ln R U S E R_{\mathrm{t}-2}$ & $\begin{array}{c}-0.0114^{+} \\
(1.94)\end{array}$ & $\begin{array}{c}-0.0104 \\
(1.35)\end{array}$ & $\begin{array}{c}-0.0079 \\
(1.50)\end{array}$ & $\begin{array}{c}-0.0040 \\
(0.73)\end{array}$ & $\begin{array}{c}-0.0037 \\
(0.51)\end{array}$ & $\begin{array}{c}-0.0003 \\
(0.06)\end{array}$ \\
\hline$\Delta \ln L T V_{\mathrm{t}-2}$ & & & & $\begin{array}{c}-0.0798 * \\
(2.10)\end{array}$ & $\begin{array}{c}-0.0978^{*} \\
(2.45)\end{array}$ & $\begin{array}{c}-0.0813^{*} \\
(2.40)\end{array}$ \\
\hline$\Delta \ln L T V_{\mathrm{t}-3}$ & & & & $\begin{array}{r}-0.024 \\
(0.76)\end{array}$ & $\begin{array}{c}-0.0535 \\
(1.38)\end{array}$ & $\begin{array}{c}-0.0225 \\
(0.69)\end{array}$ \\
\hline Adjusted $\mathrm{R}^{2}$ & 0.846 & 0.823 & 0.876 & 0.878 & 0.860 & 0.907 \\
\hline S.E.× 100 & 0.364 & 0.350 & 0.327 & 0.324 & 0.311 & 0.282 \\
\hline VEC LM(2) & 0.28 & 1.51 & 8.15 & 1.77 & 10.62 & 4.93 \\
\hline VEC LM(8) & 7.86 & 7.82 & 7.00 & 7.89 & 10.94 & 7.49 \\
\hline
\end{tabular}

Notes:

(i) The symbols ${ }^{+},{ }^{*}$ and ${ }^{* *}$ denote significance at the $90 \%, 95 \%$ and $99 \%$ levels respectively. Absolute t-statistics are given in parentheses. S.E. is the equation standard error. The VEC LM statistics are systems Lagrange Multiplier tests statistics for $2^{\text {nd }}$ or $8^{\text {th }}$ order autocorrelation.

(ii) Models 1 to 6 were estimated using lag lengths of 5, 5, 4, 4, 5 and 5 respectively. These lag lengths minimized the Akaike Information Criterion (AIC) and, except for non-LTV models, yielded clean residuals and unique, significant cointegrating vectors.

(iii) In Part (B), the estimated coefficients on lags of first difference terms longer than t-2 are omitted to conserve space.

(iv) Augmented Dickey Fuller (ADF) unit root tests statistics are set out below. The data period is 1979q1 to 2007q2. The lag lengths in the ADF regressions, which included deterministic time trends, were chosen using the AIC.

\begin{tabular}{l}
\multicolumn{1}{c}{ Variable } \\
$\ln H P R E N T_{t}$ \\
$\Delta \ln H P R E N T_{\mathrm{t}}$ \\
$\ln R U S E R_{\mathrm{t}}$ \\
$\Delta \ln R U S E R_{\mathrm{t}}$ \\
$\ln L T V_{\mathrm{t}}$ \\
$\Delta \ln L T V_{\mathrm{t}}$
\end{tabular}

ADF Statistic
1.8543
$4.2759^{* *}$
2.8738
$4.0394 * *$
2.1391
$4.9066^{* *}$

\begin{tabular}{cc}
\multicolumn{2}{c}{ ADF Critical Values } \\
$5 \%$ & $1 \%$ \\
3.4497 & 4.0405 \\
3.4497 & 4.0405 \\
3.4497 & 4.0405 \\
3.4497 & 4.0405 \\
3.4520 & 4.0452 \\
3.4545 & 4.0505
\end{tabular}

AIC Lag

Length

4

4

3

1

3

8 
Table 2: Autoregressive Distributed Lag Models of the Change in U.S. Log Price-Rent Ratio 1980q1-2001q4 and 1980q1-2007q2

No LTV Term

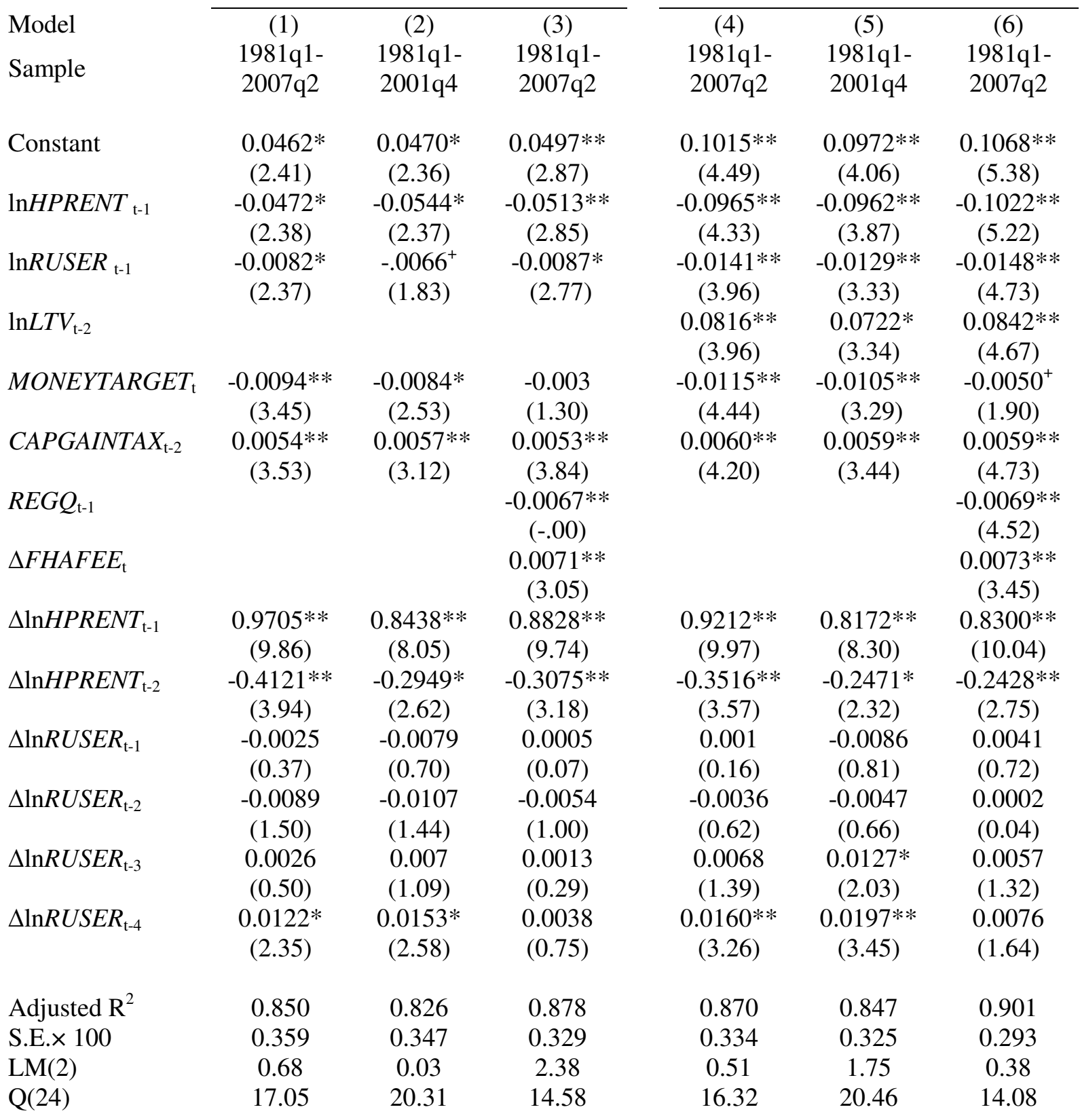

Notes: See Table 1. $\mathrm{LM}(2)$ is the Breusch-Godfrey Lagrange Multiplier test for $\mathrm{AR}(2) / \mathrm{MA}(2)$ errors. $\mathrm{Q}(24)$ is the Ljung-Box Q-statistic for white noise residuals using 24 lags. 
Table 3: Alternative ARDL Models of the Change in the U.S. Log House Price-to-Rent Ratio

\begin{tabular}{|c|c|c|c|c|c|c|}
\hline \multirow[b]{2}{*}{ Model } & \multicolumn{2}{|c|}{$\begin{array}{l}\text { Home Improvement } \\
\text { Adjusted House Prices }\end{array}$} & \multicolumn{4}{|c|}{ Assumed LTV Path 2007 q3 to 2009 q3 } \\
\hline & (1) & $(2)$ & (3) & (4) & $(5)$ & (6) \\
\hline Sample & $\begin{array}{l}1980 \mathrm{q} 4- \\
2007 \mathrm{q} 2\end{array}$ & $\begin{array}{l}1980 \mathrm{q} 4- \\
2007 \mathrm{q} 2\end{array}$ & $\begin{array}{l}1980 q 4- \\
2009 q 4\end{array}$ & $\begin{array}{l}1980 \mathrm{q} 4- \\
2009 \mathrm{q} 4\end{array}$ & $\begin{array}{l}1980 \mathrm{q} 4- \\
2009 \mathrm{q} 4\end{array}$ & $\begin{array}{l}1980 \mathrm{q} 4- \\
2009 \mathrm{q} 4\end{array}$ \\
\hline Constant & $\begin{array}{l}0.0413^{*} \\
(2.11)\end{array}$ & $\begin{array}{c}0.0687 * * \\
(3.34)\end{array}$ & $\begin{array}{l}0.0763 * * \\
(5.00)\end{array}$ & $\begin{array}{l}0.1020 * * \\
(6.56)\end{array}$ & $\begin{array}{l}0.0967 * * \\
(5.58)\end{array}$ & $\begin{array}{l}0.0919 * * \\
(6.01)\end{array}$ \\
\hline $\ln H P R E N T_{\mathrm{t}-1}$ & $\begin{array}{c}-0.0487 * \\
(2.15)\end{array}$ & $\begin{array}{l}-0.0733 * * \\
(3.19)\end{array}$ & $\begin{array}{c}-0.0742 * * \\
(4.92)\end{array}$ & $\begin{array}{l}-0.0991 * * \\
(6.47)\end{array}$ & $\begin{array}{l}-0.0942 * * \\
(5.51)\end{array}$ & $\begin{array}{l}-0.0894 * * \\
\quad(5.94)\end{array}$ \\
\hline $\ln L T V_{\mathrm{t}-2}$ & & $\begin{array}{l}0.0571^{* *} \\
(3.17)\end{array}$ & $\begin{array}{l}0.0683 * * \\
(3.70)\end{array}$ & $\begin{array}{l}0.0786^{* * *} \\
(4.63)\end{array}$ & $\begin{array}{l}0.0733 * * \\
(4.16)\end{array}$ & $\begin{array}{c}0.0698 * * \\
(4.21)\end{array}$ \\
\hline $\ln R U S E R_{\mathrm{t}-1}$ & $\begin{array}{c}-0.0069 * \\
(1.99)\end{array}$ & $\begin{array}{l}-0.0091 * * \\
(2.70)\end{array}$ & $\begin{array}{c}-0.0096^{* *} \\
(3.74)\end{array}$ & & & \\
\hline $\ln R U C A D J_{\mathrm{t}-1}$ & & & & $\begin{array}{c}-0.0138^{* *} \\
\quad(5.33)\end{array}$ & $\begin{array}{c}-0.0131 * * \\
(4.76)\end{array}$ & $\begin{array}{c}-0.0125^{* *} \\
(4.95)\end{array}$ \\
\hline$F H A L T V G A P_{\mathrm{t}-2}$ & & & & & $\begin{array}{c}0.0131 \\
(0.59)\end{array}$ & \\
\hline MONEYTARGET $T_{\mathrm{t}-1}$ & $\begin{array}{c}-0.0014 \\
(0.52)\end{array}$ & $\begin{array}{c}-0.0013 \\
(0.49)\end{array}$ & $\begin{array}{c}-0.0046^{+} \\
(1.69)\end{array}$ & $\begin{array}{c}-0.0057 * \\
(2.34)\end{array}$ & $\begin{array}{c}-0.0032 \\
(1.25)\end{array}$ & $\begin{array}{l}-0.003 \\
(1.19)\end{array}$ \\
\hline CAPGAINTAX $X_{\mathrm{t}-2}$ & $\begin{array}{l}0.0052^{* *} \\
(3.71)\end{array}$ & $\begin{array}{l}0.0048^{* *} \\
(3.58)\end{array}$ & $\begin{array}{l}0.0057^{* *} \\
(4.03)\end{array}$ & $\begin{array}{c}0.0063^{* *} \\
(4.80)\end{array}$ & $\begin{array}{l}0.0058^{* *} \\
(4.49)\end{array}$ & $\begin{array}{l}0.0057^{* *} \\
(4.48)\end{array}$ \\
\hline$R E G Q_{\mathrm{t}-1}$ & $\begin{array}{c}-0.0062 * * \\
(3.69)\end{array}$ & $\begin{array}{c}-0.0061^{* *} \\
(3.81)\end{array}$ & $\begin{array}{l}-0.0050 * * \\
\quad(3.00)\end{array}$ & $\begin{array}{c}-0.0060^{* *} \\
(4.16)\end{array}$ & $\begin{array}{l}-0.0074 * * \\
(5.06)\end{array}$ & $\begin{array}{l}-0.0074 * * \\
(5.08)\end{array}$ \\
\hline$\triangle F H A F E E_{\mathrm{t}}$ & $\begin{array}{c}0.0063^{*} \\
(2.55)\end{array}$ & $\begin{array}{l}0.0064 * * \\
(2.73)\end{array}$ & $\begin{array}{l}0.0062 * \\
(2.47)\end{array}$ & $\begin{array}{l}0.0067 * * \\
(2.93)\end{array}$ & $\begin{array}{c}0.0073 * * \\
(4.15)\end{array}$ & $\begin{array}{c}0.0072 * * \\
(3.29)\end{array}$ \\
\hline$\triangle \ln H P R E N T_{\mathrm{t}-1}$ & $\begin{array}{c}0.9195^{* * *} \\
(10.07)\end{array}$ & $\begin{array}{c}0.8868^{* * *} \\
(10.11)\end{array}$ & $\begin{array}{c}1.0597 * * \\
(13.22)\end{array}$ & $\begin{array}{c}0.9691 * * \\
(13.07)\end{array}$ & $\begin{array}{c}0.9634 * * \\
(13.40)\end{array}$ & $\begin{array}{c}0.9683 * * \\
(13.60)\end{array}$ \\
\hline$\triangle \ln H P R E N T_{\mathrm{t}-2}$ & $\begin{array}{c}-0.2890^{* *} \\
(2.95)\end{array}$ & $\begin{array}{c}-0.2568^{* *} \\
(0.73)\end{array}$ & $\begin{array}{c}-0.4936^{* * *} \\
(5.80)\end{array}$ & $\begin{array}{c}-0.4158^{* *} \\
(6.03)\end{array}$ & $\begin{array}{c}-0.3707 * * \\
(4.53)\end{array}$ & $\begin{array}{c}-0.3990 * * \\
(6.00)\end{array}$ \\
\hline$\Delta \ln R U S E R_{\mathrm{t}-1}$ & $\begin{array}{l}0.002 \\
(0.44)\end{array}$ & $\begin{array}{c}0.0032 \\
(0.73)\end{array}$ & $\begin{array}{c}0.0042 \\
(0.79)\end{array}$ & $\begin{array}{c}0.0072 * \\
(1.98)\end{array}$ & $\begin{array}{c}0.0083^{*} \\
(2.23)\end{array}$ & $\begin{array}{c}0.0075^{*} \\
(2.17)\end{array}$ \\
\hline$\Delta \ln R U S E R_{\mathrm{t}-2}$ & $\begin{array}{c}-0.0049 \\
(1.12)\end{array}$ & $\begin{array}{c}-0.0031 \\
(0.73)\end{array}$ & $\begin{array}{c}-0.0085^{+} \\
(1.74)\end{array}$ & $\begin{array}{c}-0.0034 \\
(0.98)\end{array}$ & $\begin{array}{c}-0.0031 \\
(0.85)\end{array}$ & $\begin{array}{l}0.004 \\
(1.19)\end{array}$ \\
\hline$\triangle \ln R U S E R_{\mathrm{t}-3}$ & $\begin{array}{c}-0.0002 \\
(0.06)\end{array}$ & $\begin{array}{c}0.0011 \\
(0.27)\end{array}$ & $\begin{array}{c}0.0036 \\
(0.74)\end{array}$ & $\begin{array}{l}0.0025 \\
(0.73)\end{array}$ & $\begin{array}{c}-0.00001 \\
(0.00)\end{array}$ & $\begin{array}{c}-0.0008 \\
(0.23)\end{array}$ \\
\hline$\Delta \ln R U S E R_{\mathrm{t}-4}$ & $\begin{array}{c}0.0065 \\
(1.47)\end{array}$ & $\begin{array}{c}0.0080^{+} \\
(1.89)\end{array}$ & $\begin{array}{l}0.0039 \\
(0.80)\end{array}$ & $\begin{array}{l}0.0017 \\
(0.52)\end{array}$ & $\begin{array}{c}0.0012 \\
(0.33)\end{array}$ & $\begin{array}{c}0.0003 \\
(0.08)\end{array}$ \\
\hline FINCRISIS $_{\mathrm{t}}$ & & & $\begin{array}{c}-0.0039 \\
(1.03)\end{array}$ & $\begin{array}{c}-0.0017 \\
(0.49)\end{array}$ & $\begin{array}{c}-0.0012 \\
(0.33)\end{array}$ & $\begin{array}{c}-0.0007 \\
(0.20)\end{array}$ \\
\hline $100 \times D C R E X O G_{\mathrm{t}}$ & & & & & $\begin{array}{c}0.0090 * * \\
(2.97)\end{array}$ & $\begin{array}{c}0.0092 * * \\
(3.08)\end{array}$ \\
\hline Adjusted $\mathrm{R}^{2}$ & 0.878 & 0.889 & 0.910 & 0.925 & 0.931 & 0.931 \\
\hline $100 \times$ Std. Error & 0.344 & 0.329 & 0.350 & 0.318 & 0.306 & 0.305 \\
\hline $\operatorname{LM}(2)$ & 1.6 & 0.70 & 2.35 & 0.65 & 0.34 & 0.24 \\
\hline $\mathrm{Q}(24)$ & 13.44 & 9.85 & 24.53 & 21.22 & 16.4 & 17.86 \\
\hline
\end{tabular}

Notes: See Tables 1 and 2. Longer lags on the first differences of the log house price-to-rent and real user cost terms were included in models 1 and 4, but the estimates are not reported here. 


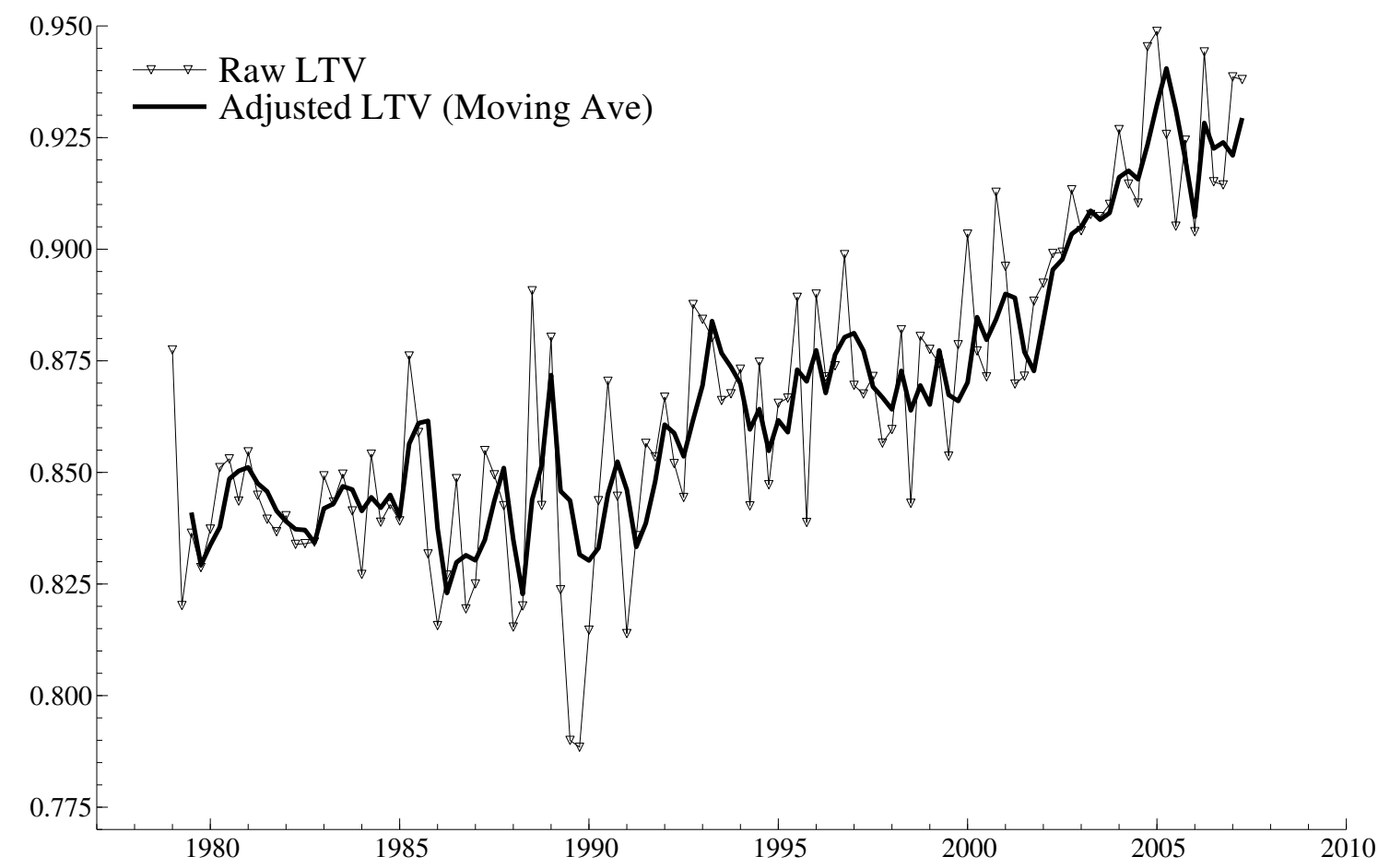

Fig. 1: Raw and Adjusted Loan to Value (LTV) Ratios for First Time Home Buyers, 1979 q1 to 2007 q2. The dip in the raw LTV series in the late 1980's is due to the Savings and Loan crisis. Source: American Housing Survey and Duca, Johnson and Muellbauer (2009). 


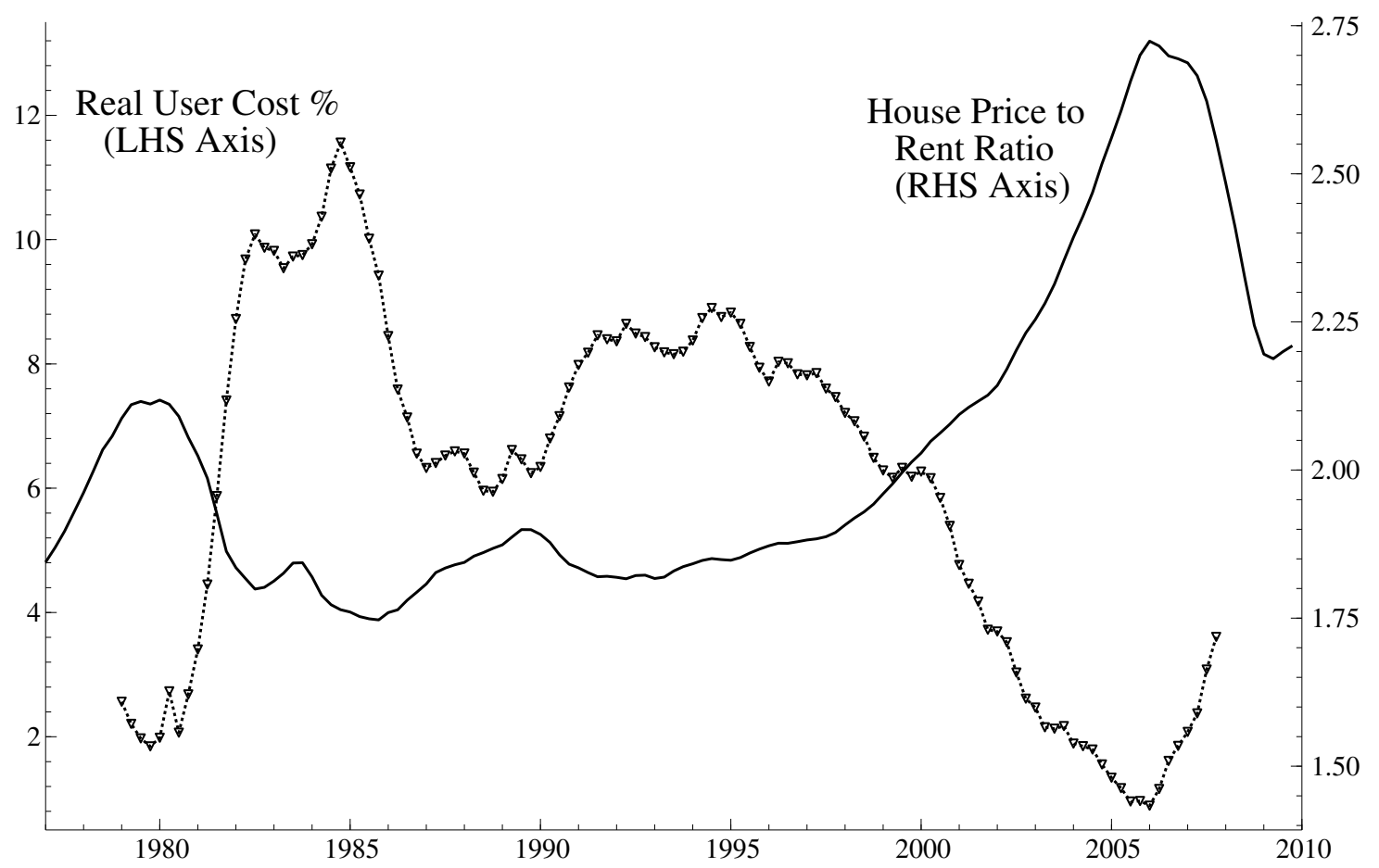

Fig. 2: The Real User Cost of Housing and the House Price-to-Rent Ratio. 


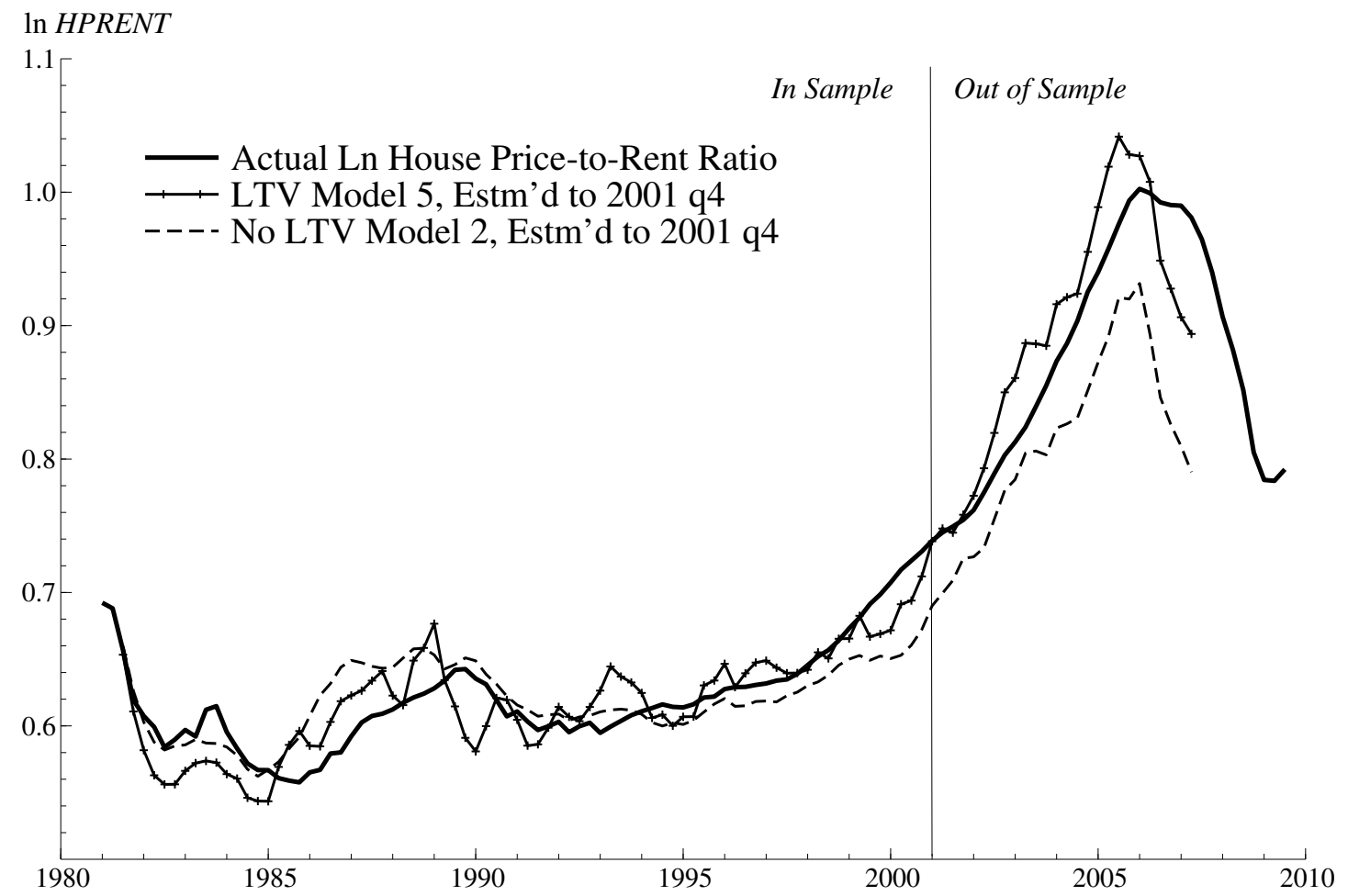

Fig. 3: The Estimated Equilibrium Log House Price-to-Rent Ratios from LTV and Non-LTV Models. The Figure is based on the model 2 and 5 results in Table 1, which were estimated over the pre-subprime boom sample, 1981 q1 to 2001 q4. The LTV model tracks the data better out-of-sample. 


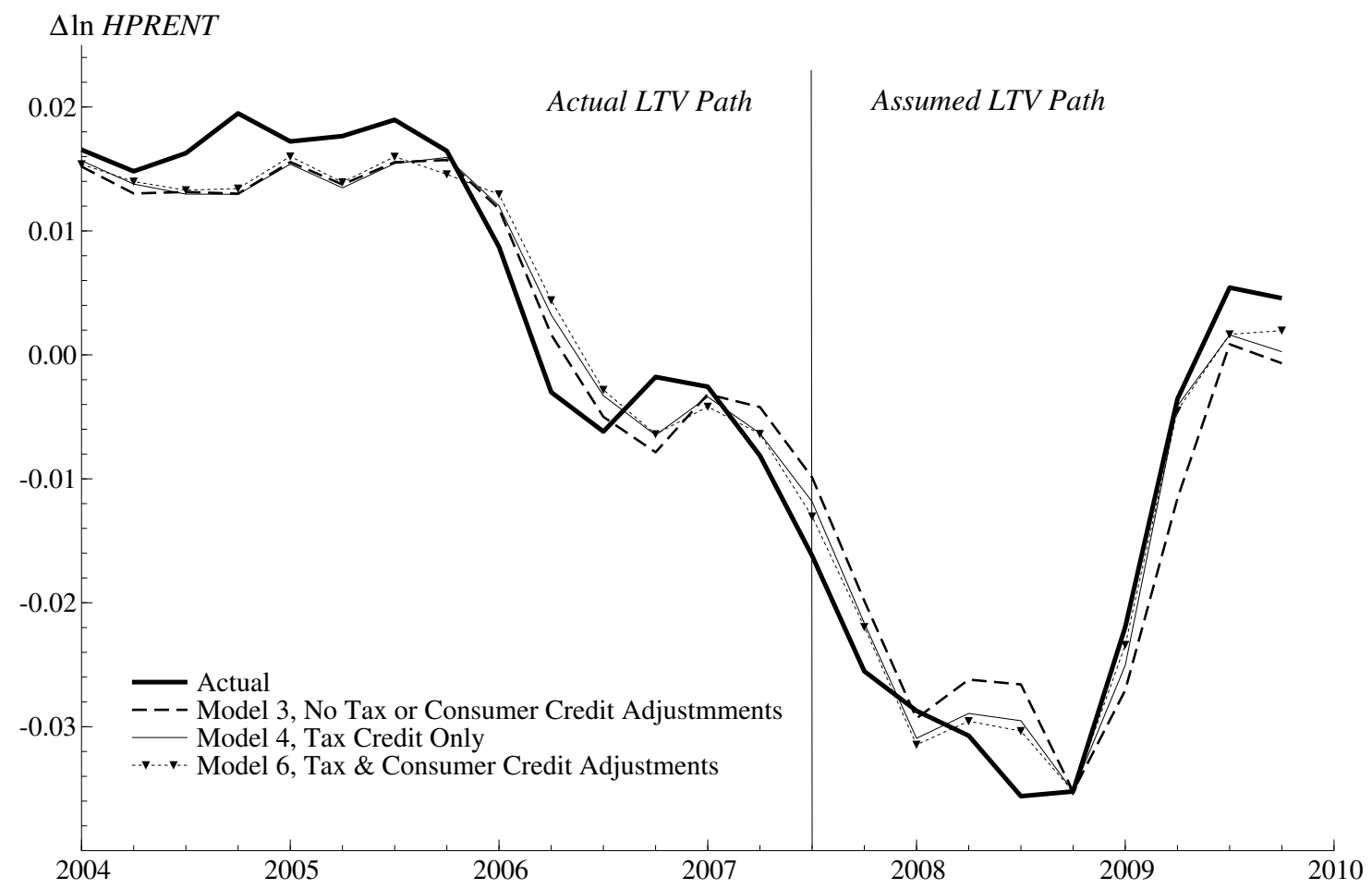

Fig. 4: The Actual and Simulated Change in the Log House Price-to-Rent Ratio from $2007 q 3$ to $2009 q 4$. The Figure is based on the model 3, 4 and 6 results in Table 3. 


\section{BIS Department tor Business

\section{Spatial Economics Research Centre (SERC)}

London School of Economics

Houghton Street

London WC2A 2AE

Tel: 02078523565

Fax: 02079556848

Web: www.spatialeconomics.ac.uk

SERC is an independent research centre funded by the Economic and Social Research Council (ESRC), Department for Business Innovation and Skills (BIS), the Department for Communities and Local Government (CLG) and the Welsh Assembly Government. 